\title{
PROGRESS IN PRIMARY ALDOSTERONISM
}

\section{Mineralocorticoid receptor antagonists and management of primary aldosteronism in pregnancy}

\author{
Anna Riester and Martin Reincke \\ Medizinische Klinik und Poliklinik IV, Klinikum der Ludwig-Maximilians-Universität München, Ziemssenstraße 1, \\ 80336 Munich, Germany
}

\author{
Correspondence \\ should be addressed \\ to M Reincke \\ Email \\ martin.reincke@ \\ med.uni-muenchen.de
}

\begin{abstract}
Primary aldosteronism (PA) is the most common cause of secondary hypertension. In this review, we discuss the diagnosis and management of PA during pregnancy based on the literature. As aldosterone and renin are physiologically increased during pregnancy and confirmation tests are not recommended, the diagnosis of PA during pregnancy relies on a repeatedly suppressed plasma renin level. Mineralocorticoid receptor antagonists (MRAs) are the most effective drugs to treat hypertension and hypokalemia in patients with PA. However, spironolactone (FDA pregnancy category C) might lead to undervirilization of male infants due to the anti-androgenic effects. Although data in the literature are very limited, treatment with spironolactone is not recommended. Eplerenone (FDA pregnancy category B) is a selective MRA without anti-androgenic potential. If MRA treatment is required in pregnancy, eplerenone appears to be a safe and effective alternative, although symptomatic treatment with approved antihypertensive drugs and supplementation with potassium is the first choice. In case of aldosterone-producing adenoma, laparoscopic adrenalectomy is a therapeutic option in the second trimester of pregnancy.
\end{abstract}

Invited Authors' profiles:

Martin Heinrich Reincke is the director of the Medizinische Klinik and Poliklinik IV, Ludwig-Maximilians University in Munich and chair of the Department of Endocrinology and Diabetology. His research specialities include adrenal physiology and pathophysiology, endocrine hypertension, pituitary disease, mineralocorticoid and glucocorticoid action and stress research. Professor Reincke is heading a research team specifically exploring the prevalence and relevance of mineralocorticoid excess in resistant hypertension at epidemiological, clinical, genetic, and molecular levels.

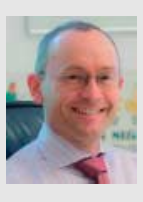

Anna Riester is a resident physician at the University of Munich Hospital, Germany. She received her doctoral degree working on 'Urocortin dependent effects on the adrenal gland in vivo' in the working group of Prof. Beuschlein. In 2010, Dr Riester stayed at the Weizmann Institute of Science, Rehovot, Israel, for a research internship and worked on microRNA and the adrenal gland. She is a member of the research team of Prof. Reincke and working on clinical and transclinical studies in the German Conn's Registry. 


\section{Physiological changes in the renin- angiotensin-aldosterone system during pregnancy}

In pregnancy, the renin-angiotensin-aldosterone system (RAAS) plays an important role for the equilibrium of salt and water in mother and child. All components of the RAAS are altered during pregnancy $(1,2)$. Renin concentrations are elevated due to extra-renal secretion in decidua and ovaries through estrogen stimulation (2). An increase in angiotensinogen production in the liver is observed in pregnant women. By contrast, the angiotensin-converting enzyme is reduced. These changes result in an elevation in aldosterone and angiotensin II (ANGII) levels (3). Increased aldosterone secretion is also a physiological response to sodium loss in response to high progesterone concentrations, a competitive inhibitor of aldosterone at the renal tubulus (4). Therefore, owing to this peculiar balance between progesterone and aldosterone, no increase in blood pressure is found in healthy pregnant women. Additionally, ANGII is not as effective as in nonpregnant women through changes in the $\mathrm{AT}_{1}$-receptor sensitivity, elevated progesterone levels, and elevated prostacyclin levels (5). Besides the systemic reninangiotensin-system (RAS), a local extra-renal RAS is suggested to be in site in the placenta regulating the feto-placental circulation (6). Pre-eclampsia is a disease in pregnant women characterized by the combination of hypertension and proteinuria. Besides placental abnormalities, alterations in the RAAS system are assumed to play a major role for its pathogenesis. In patients with pre-eclampsia, decreased levels of renin, ANGI, ANGII, and aldosterone are found $(1,7)$ and the ANGII sensitivity is increased through $\mathrm{AT}_{1}$ receptor heterodimers $(8,9)$. Although the pathogenesis of pre-eclampsia remains quite unclear, autoantibodies stimulating the $\mathrm{AT}_{1}$ receptor $\left(\mathrm{AT}_{1}-\mathrm{AA}\right)$ and/or placental hypoxia may contribute to the development of pre-eclampsia $(10,11)$. This concept is supported by experiments in rodent models. $\mathrm{AT}_{1}$-AA injections in pregnant mice lead to hypertension and proteinuria (12). After reduction of uterine perfusion pressure, $\mathrm{AT}_{1}$-AA was detectable together with pre-eclamptic symptoms in pregnant rats $(13,14)$. Recently, Rossitto et al. (15) and Kem et al. (16) reported high titers of $\mathrm{AT}_{1}-\mathrm{AA}$, especially in PA patients with aldosterone-producing adenoma (APA). Therefore, the underlying pathophysiology of pre-eclampsia and APA might be partially similar. However, further investigations are necessary.

\section{PA and pregnancy}

Hypertensive disorders affect $6-8 \%$ of all pregnant women and are leading causes of maternal and perinatal mortality and morbidity $(17,18,19)$.

It is difficult to estimate as to how many of these pregnant women are affected by primary aldosteronism (PA). However, assuming that $\sim 10 \%$ of all hypertensive disorders are caused by PA, $0.6-0.8 \%$ of all pregnant women would suffer from PA. Indeed, to our knowledge, only $41 \mathrm{PA}$ patients with 47 pregnancies (excluding familial forms) have been published in the literature regarding PA and pregnancy $(20,21,22,33)$ (methods for literature review, see Supplementary data, see section on supplementary data given at the end of this article). PA is mostly caused by idiopathic bilateral hyperplasia of the adrenal gland (IAH) or APA, whereas APA might be more frequent than IAH as shown in the PAPY study and in our own data $(34,35)$. In PA, the median age at diagnosis is $\sim 50$ years. However, the onset of PA might be earlier as the diagnosis is often delayed (34). Therefore, most female patients are diagnosed after the reproductive period. However, there are a few familial forms of PA (types I, II, and III) in $\sim 1 \%$ of the PA patients (36). Familial hyperaldosteronism is important in the context of PA and pregnancy, as women are affected in the reproductive period due to its early onset.

Most of the data on pregnancy and PA were obtained from patients with glucocorticoid-remediable aldosteronism (GRA). Responsible for GRA is a hybrid gene caused by unequal crossing resulting in a fusion of the $5^{\prime}$ regulatory region of the CYP11B1 and the coding region of the CYP11B2. Therefore, the expression of aldosterone synthase is adrenocorticotropin sensitive and patients are treated with low-dose dexamethasone. However, physiological elevation in the adrenocorticotropin level caused by production of corticotropin-releasing hormone in the placenta may lead to an exacerbation of blood pressure (37). In a large retrospective study, Wyckhoff et al. described 35 pregnancies in 16 females with GRA. Hypertension was present in 26 of the 35 pregnancies and two (6\%) were complicated by superimposed preeclampsia. This rate is not higher than that in the general population (2.5-10\%) (18). In a Sardinian family, none of the 29 pregnancies in eight GRA-affected mothers were complicated by severe hypertension or pre-eclampsia (38). However, 39\% of women developed an aggravated hypertension during pregnancy, which was associated with a lower birth weight; $23 \%$ had to be treated with medication including $\alpha$-methyldopa, potassium-sparing diuretics, $\beta$-blocker, and thiazide diuretics. 
Unfortunately, in patients with PA caused by APA or IAH, no studies in large cohorts exist - therefore, the evidence is based on single case reports. The course of hypertension during pregnancy in patients affected by sporadic PA appears to be highly variable and not predictable: case reports describe worsening of hypertension and hypokalemia as well as spontaneous improvement or even normotension independent of the PA subtype (39). The interaction between plasma aldosterone and its physiological antagonist progesterone may explain this variable course. Ronconi et al. hypothesized that the clinical consequences of PA, hypertension and hypokalemia, during pregnancy only develop if the amount of progesterone is unable to compensate the aldosterone excess. Therefore, the authors suggest calculating the progesterone-to-aldosterone ratio as a measure of mineralocorticoid excess during pregnancy. In healthy pregnant women, this ratio increases during pregnancy (values between 18 and $80 \mathrm{pmol} / \mathrm{l} / \mathrm{pmol} / \mathrm{l}$ ) as progesterone increases $\sim 1000$ times and aldosterone approximately ten times. Shortly after delivery, the progesteroneto-aldosterone ratio falls to very low values (4). In the single case described by Ronconi et al., a ratio below $20 \mathrm{pmol} / \mathrm{l} / \mathrm{pmol} / \mathrm{l}$ was associated with hypertension. Therefore, a ratio above this cutoff might be useful as a predictor for a favorable outcome (39). This is an interesting observation and should be evaluated in a larger cohort.

The outcome of mother and child mainly depends on the blood pressure. Case reports describe uneventful pregnancies with healthy newborns (e.g. $(40,41)$ ). Nevertheless, end-organ damage, preterm delivery, and placental abruption are potential complications (39).

\section{Diagnosing PA during pregnancy}

Diagnosing PA during pregnancy is challenging. Therefore, it is the first step to consider PA as a reason for hypertension in pregnancy. Hypokalemia and/or severe hypertension in a pregnant woman should lead to screening for PA, especially if the onset is before pregnancy or before the 20th week of gestation. After the 20th week of gestation, the probability of developing pre-eclampsia associated with non-PA causes is higher. According to the guidelines, pre-eclampsia is defined as hypertension with proteinuria or hypertension with associated laboratory abnormalities, pulmonary edema, or neurological symptoms (42). However, superimposed pre-eclampsia develops in $13-40 \%$ of women with chronic hypertension.

Nevertheless, if the signs described above for preeclampsia are missing, and especially in the presence of hypokalemia, PA should be ruled out. To confirm or rule out the diagnosis of PA in pregnant women is a challenge as well. As the plasma aldosterone level is physiologically elevated in pregnancy, the only way to diagnose PA is via the suppressed plasma renin concentration, which is physiologically elevated in pregnancy. Therefore, in healthy pregnant women, the aldosterone-to-renin ratio (ARR) is low, whereas in pregnant women with PA the ARR is elevated. However, it might be false negative (43). Confirmation tests as saline infusion tests or captopril tests are not recommended in pregnancy due to risks associated with volume expansion or toxic effects (44). Therefore, the diagnosis of PA has to be based only on suppressed renin and elevated ARR (see Fig. 1). Subtype diagnosis during pregnancy is based on imaging as the prevalence of hormone-inactive adenoma in young patients below 40 years is very low and adrenal vein sampling is not recommended due to radiation exposure. Imaging of the adrenal gland with MRI or ultrasonography may be performed during pregnancy. However, if blood pressure and hypokalemia are well controlled during pregnancy, postponing the subtype diagnosis including adrenal vein sampling after delivery is recommended (45).

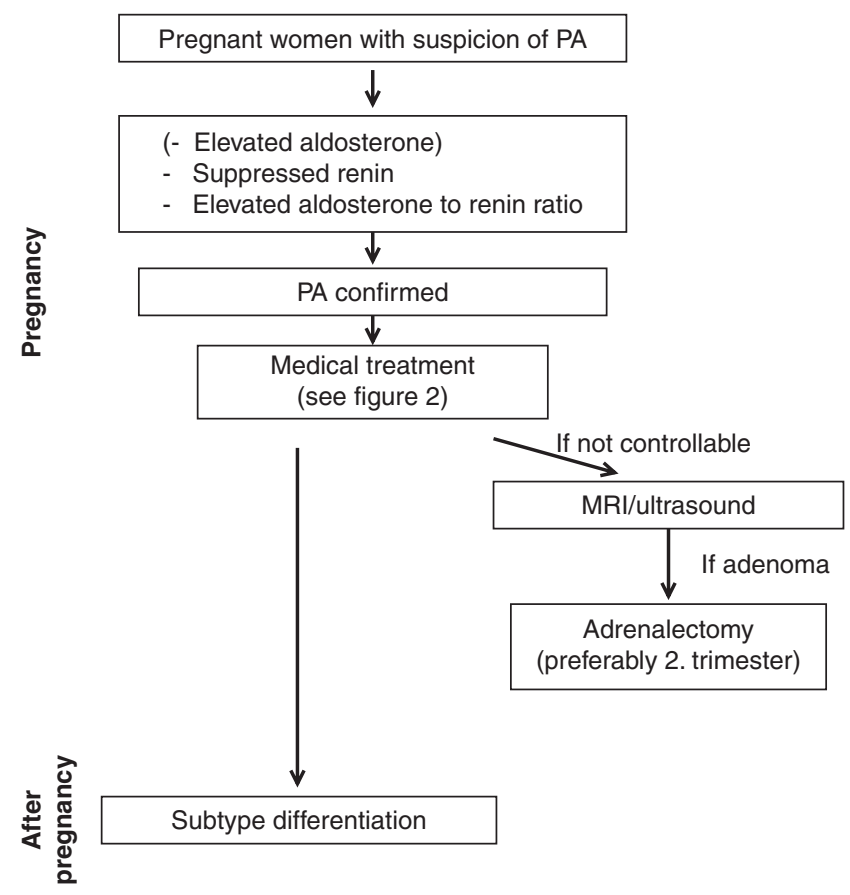

Figure 1

Diagnosis of primary aldosteronism during pregnancy. PA, primary aldosteronism; MRI, magnetic resonance imaging; MRA, mineralocorticoid receptor antagonist. 
Treatment with antihypertensive drugs or even adrenalectomy in these newly diagnosed patients depends on clinical presentation and does not differ from the approach in already diagnosed patients as described below.

In patients with inconclusive results, we recommend the diagnostic work-up including confirmation tests after delivery and after the breastfeeding period.

\section{Mineralocorticoid receptor antagonist treatment in pregnancy and breastfeeding period}

Mineralocorticoid receptor antagonists (MRAs) are the first choice for medical treatment of PA. Unfortunately, spironolactone is classified as FDA pregnancy category C: animal reproduction studies have shown an adverse effect on the fetus and there are no adequate and well-controlled studies in humans. Eplerenone, on the other hand, is classified as pregnancy category B: no adequate and well-controlled studies in pregnant women are available. In the following paragraphs, the existing data on the use of these drugs in pregnancy are discussed.

\section{Spironolactone in pregnancy}

Spironolactone was introduced in 1960 as the first MRA and is widely used in different indications such as liver cirrhosis with ascites, heart failure, hypertension, and PA $(46,47)$. However, spironolactone was never proved to be safe in pregnancy. Nevertheless, as indicated by Morton et al. (48), spironolactone was commonly used in hypertension, pre-eclampsia, liver disease, and myasthenia gravis in pregnancy before 1980. Two trials exist investigating the effect of spironolactone treatment on the RAAS and the excretion of different steroids in pregnant women with edema $(49,50)$. It is known that spironolactone crosses the placenta (44) and therefore might have an impact on the fetus. As testosterone is necessary for male morphogenesis, the anti-androgenic activity of spironolactone has to be considered. In an experiment on rats, Rose et al. (51) failed to show the effects of spironolactone on male genital development with an equivalent to the $100 \mathrm{mg}$ adult human regimen. However, 5 years later, Hecker et al. (52) published a first study describing feminization in male rat fetuses after treatment of female rats (body weight of $\sim 200 \mathrm{~g}$ ) from the 13th to the 21st day p.c. with a higher dose of spironolactone (40 mg/day). In the FDA report of aldactone, teratology studies on mice, rats, and rabbits are mentioned (http:// www.accessdata.fda.gov/drugsatfda_docs/label/2013/ 012151s071lbl.pdf, 30 May 2014). No teratogenic or embryotoxic effects could be observed in mice. However, in rats treated with very high doses $(200 \mathrm{mg} / \mathrm{kg}$ per day), feminization of male fetuses was observed. In rabbits

Table 1 Spironolactone as a therapeutic drug in pregnancy.

\begin{tabular}{|c|c|c|c|c|c|c|c|}
\hline First author & $\begin{array}{c}\text { Year of } \\
\text { publication }\end{array}$ & Reasons & $\begin{array}{l}\text { Dosage per } \\
\text { day }(\mathrm{mg})\end{array}$ & $\begin{array}{l}\text { Weeks of } \\
\text { gestation }\end{array}$ & $\begin{array}{c}\text { No. of } \\
\text { pregnancies }\end{array}$ & Infants & $\begin{array}{l}\text { Outcomes and } \\
\text { comments }\end{array}$ \\
\hline Crane (59) & 1964 & PA & 800 & $\begin{array}{l}32 \text { (only for } \\
2 \text { days) }\end{array}$ & 1 & 1 male & $\begin{array}{l}\text { Stillbirth } 32 \text { nd week } \\
\text { of gestation, abrup- } \\
\text { tio placentae }\end{array}$ \\
\hline Levy (57) & 1971 & PA & & $\sim \geq 12$ & 1 & 1 male & $\begin{array}{l}\text { CS, hyperkalemia of } \\
\text { the infant after } \\
\text { potassium infusion } \\
\text { peripartal }\end{array}$ \\
\hline Lammintausta (50) & 1979 & $\begin{array}{c}\text { Pregnancy } \\
\text { edema }\end{array}$ & 100 & $\begin{array}{l}\geq 24 \text { (for } \\
\quad \geq 2 \text { weeks) }\end{array}$ & 10 & 10 & - \\
\hline Lotgering (58) & 1986 & PA & 300 & $\geq 22$ & 1 & 1 female & SGA \\
\hline Groves (41) & 1995 & $\begin{array}{l}\text { Bartter } \\
\text { syndrome }\end{array}$ & $\leq 400$ & & 3 & $\begin{array}{l}2 \text { males, } \\
1 \text { female }\end{array}$ & No complications \\
\hline Rigo (40) & 1995 & $\begin{array}{l}\text { Bartter } \\
\text { syndrome }\end{array}$ & & & 2 & $\begin{array}{l}1 \text { male, } \\
1 \text { female }\end{array}$ & No complications \\
\hline Nohira (54) & 2001 & $\begin{array}{l}\text { Bartter } \\
\text { syndrome }\end{array}$ & & $\geq 31$ & 1 & 1 female & SGA \\
\hline De Arriba (55) & 2009 & $\begin{array}{l}\text { Gitelman } \\
\text { syndrome }\end{array}$ & & $\begin{array}{c}0-17 \text { and } \\
25-35\end{array}$ & 1 & 1 male & Oligohydramnion, CS \\
\hline Shah (53) & 2011 & PCOS & & $0-5$ & 1 & 1 male & Ambiguous genitalia \\
\hline Rusavy (56) & 2012 & $\begin{array}{l}\text { Gitelman } \\
\text { syndrome }\end{array}$ & & $30-39$ & 1 & 1 female & $\begin{array}{l}\text { Diagnosis at 30th } \\
\text { week of gestation, } \\
\text { healthy infant }\end{array}$ \\
\hline
\end{tabular}

www.eje-online.org 
treated with $20 \mathrm{mg} / \mathrm{kg}$, a lower number of live fetuses was described. Overall, using an extensive PubMed and Google Scholar research, we found one case report describing an ambiguous genitalia in a human newborn of a mother treated with spironolactone until the 5th week of gestation for PCOS (53). By contrast, there are a few case reports describing healthy newborns of mothers treated with spironolactone during pregnancy (see Table 1): case reports describe six children of three women with Bartter syndrome showing no anti-androgenic effect in three male and three female newborns $(40,41,54)$. Similarly, two case reports of mothers with Gitelman syndrome treated with spironolactone describe a healthy boy with normal growth but oligohydramnion (55) and a healthy girl respectively (56). In three case reports of PA patients, the administration of spironolactone is mentioned $(57,58,59)$. Additionally, the German database Embryotox lists three pregnancies with spironolactone treatment resulting in three healthy newborns (two males and one female) (http://www.embryotox.de/spirobeta.html, 30 May 2014).

Taken together, in each single case, it has to be discussed whether the benefits of spironolactone to control hypokalemia and hypertension outweigh the feared but only once described risk of undervirilization in male newborns. As the most important steps of sex differentiation take place in the first trimester, the anti-androgenic effects of spironolactone might only be important in the first weeks of gestation. However, especially in late pregnancy, spironolactone administered in high doses may lead to a decrease in the plasma volume due to the natriuretic effect of spironolactone, and that might result in a higher risk of intrauterine growth retardation (40).

\section{Eplerenone in pregnancy}

Eplerenone was introduced $\sim 10$ years ago as a selective MRA. In contrast to spironolactone, no anti-androgenic effects are described. As no adequate studies in pregnant women are available, the pregnancy category B has been assigned (60). In animal models, no teratogenic effects

Table 2 Eplerenone as a therapeutic drug in pregnancy.

\begin{tabular}{|c|c|c|c|}
\hline First author & $\begin{array}{c}\text { Year of } \\
\text { publication }\end{array}$ & Reasons & $\begin{array}{c}\text { Dosage per } \\
\text { day }(\mathrm{mg})\end{array}$ \\
\hline Hutter (61) & 2006 & $\begin{array}{l}\text { Diastolic heart } \\
\text { failure }\end{array}$ & \\
\hline Morton (48) & 2011 & $\begin{array}{l}\text { Gitelman } \\
\text { syndrome }\end{array}$ & 100 \\
\hline Cabassi (21) & 2012 & PA & 50 \\
\hline
\end{tabular}

were observed (FDA report Inspra Eplerenone, http:// www.accessdata.fda.gov/drugsatfda_docs/label/2008/ 021437s006lbl.pdf, 30 May 2014). We found one case report describing an uneventful pregnancy under treatment with eplerenone in a woman with APA delivering a healthy boy with a follow-up of 2 years (21). Additionally, a safe and effective use of eplerenone was reported in a mother with Gitelman syndrome (48) as well as in a mother with a diastolic heart failure (61) (see Table 2).

\section{Breastfeeding under MRA treatment}

To our knowledge, no case reports are available on treatment of PA in breastfeeding mothers. Canrenone, the major and active metabolite of spironolactone, appears in human breast milk (Aldactone, FDA report). The relative dose for the newborn is $1.2 \%$ of the daily dose of the nursing mother. Therefore, an impact on the newborn is not expected (http://www.embryotox.de/spirobeta.html, 30 May 2014). For eplerenone, no data on human breast milk are available. Preclinical data show that eplerenone is detectable in rat breast milk with a peak concentration at 30-60 min after oral dosing (eplerenone, FDA report).

Taken together, based on the presented data, we recommend the use of eplerenone in pre-pregnancy, pregnancy, and breastfeeding situation, if MRA treatment is necessary.

\section{Recommendations for treatment of PA in pregnancy and in the pre-pregnancy period}

Treatment of PA in pregnancy is challenging. Before planning pregnancy, it is highly recommended to perform adequate subtype differentiation by adrenal vein sampling (AVS). If APA is diagnosed, surgical cure by adrenalectomy should be aspired before planning pregnancy to avoid complications during pregnancy. However, the situation is more difficult in patients with IAH. In these patients, it is favorable to achieve normotensive values before pregnancy. Depending on the severity of hypertension,

PA, primary aldosteronism

\begin{tabular}{lcllll}
$\begin{array}{l}\text { Weeks of } \\
\text { gestation }\end{array}$ & $\begin{array}{c}\text { No. of } \\
\text { pregnancies }\end{array}$ & & Infants & & $\begin{array}{l}\text { Outcomes and } \\
\text { comments }\end{array}$ \\
\cline { 1 - 1 } & 1 & 1 & 1 female & Healthy infant \\
$0-39$ & 1 & 1 male & Healthy infant \\
$27-35$ (end) & 1 & &
\end{tabular}




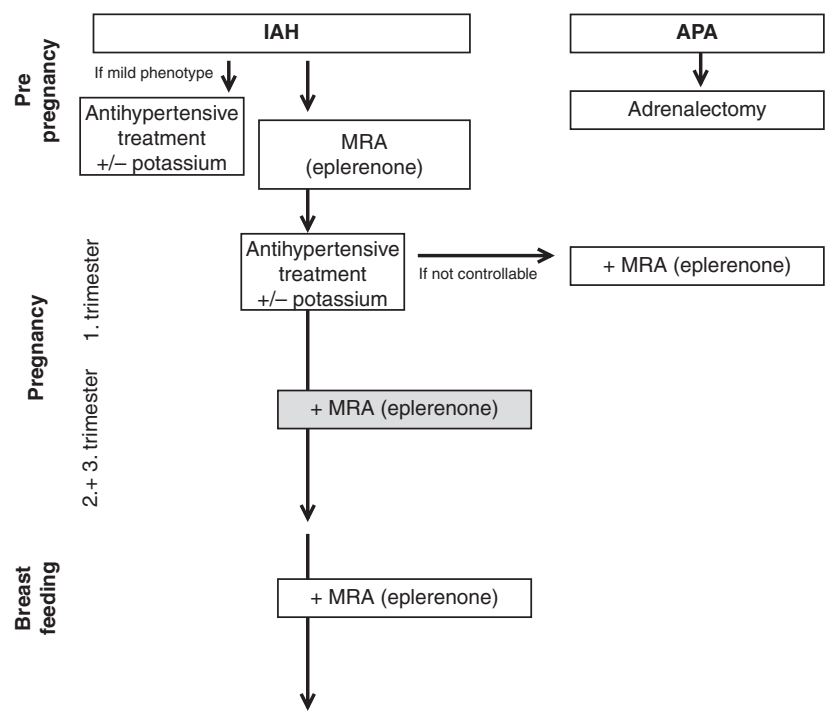

Figure 2

Treatment of primary aldosteronism in pregnancy. IAH, idiopathic adrenal hyperplasia; APA, aldosterone-producing adenoma; MRA, mineralocorticoid receptor antagonist.

different approaches are possible (Fig. 2). In normokalemic patients with well-controlled or mild hypertension, the termination of MRA treatment should be discussed. Alternatively, antihypertensive drugs with a good safety profile during pregnancy, such as $\alpha$-methyldopa and $\beta$-blockers, should be initiated already in the planning period. Nevertheless, these patients have to be monitored closely. In patients with severe PA including WHO hypertension grades 2 and 3 and hypokalemia, the termination of MRAs before pregnancy seems to be inadequate as the time of conception is not predictable. In this situation, spironolactone therapy should be continued using a low effective dose (25-50 mg of spironolactone per day). Alternatively, MRA therapy can be switched to eplerenone. As soon as the pregnancy is confirmed, we recommend stopping spironolactone as the first trimester is the most sensitive period for sex differentiation and spironolactone might lead to disturbance as described above.

If hypertension or hypokalemia are not controlled before conception or during the first trimester, we recommend the use of eplerenone as a selective MRA. In patients with APA, adrenalectomy could be considered if hypokalemia and hypertension are uncontrollable $(22,26,44)$. In these cases, a laparoscopic approach in the second trimester is recommended. PA patients could be treated again in the second and third trimesters with MRAs if necessary.
In guidelines dealing with the treatment of hypertension in pregnancy, sodium restriction is not recommended as a treatment option. Notably, the recommended blood pressure in hypertensive pregnant patients is between $120 / 80$ and 160/105 $\mathrm{mmHg}$. In hypertensive pregnant patients with evidence of end-organ damage, the recommended blood pressure level is below 140/90 $\mathrm{mmHg}(42)$.

In summary, the evidence for diagnosing and treating PA with MRAs during pregnancy and breastfeeding is limited. Recommendations given in this review are mainly based on case reports and toxicity data generated in animal studies. The paucity of data on adverse outcomes during pregnancy despite being on the market for more than 50 years is remarkable and might indicate a better safety profile than anticipated from the known anti-androgenic activities of spironolactone.

\section{Supplementary data}

This is linked to the online version of the paper at http://dx.doi.org/10.1530/ EJE-14-0444.

Declaration of interest

The authors declare that there is no conflict of interest that could be perceived as prejudicing the impartiality of the review.

Funding

This work was supported by a grant from the Else Kröner-Fresenius Stiftung to Martin Reincke.

\section{References}

1 Verdonk K, Visser W, Van Den Meiracker AH \& Danser AH. The renin-angiotensin-aldosterone system in pre-eclampsia: the delicate balance between good and bad. Clinical Science 2014126 537-544. (doi:10.1042/CS20130455)

2 Derkx FH, Alberda AT, de Jong FH, Zeilmaker FH, Makovitz JW \& Schalekamp MA. Source of plasma prorenin in early and late pregnancy: observations in a patient with primary ovarian failure. Journal of Clinical Endocrinology and Metabolism 198765 349-354. (doi:10.1210/ jcem-65-2-349)

3 Irani RA \& Xia Y. The functional role of the renin-angiotensin system in pregnancy and preeclampsia. Placenta 200829 763-771. (doi:10.1016/j.placenta.2008.06.011)

4 Ledoux F, Genest J, Nowaczynski W, Kuchel O \& Lebel M. Plasma progesterone and aldosterone in pregnancy. Canadian Medical Association Journal 1975112 943-947.

5 Gant NF, Daley GL, Chand S, Whalley PJ \& MacDonald PC. A study of angiotensin II pressor response throughout primigravid pregnancy. Journal of Clinical Investigation 197352 2682-2689. (doi:10.1172/ JCI107462)

6 Anton L \& Brosnihan KB. Systemic and uteroplacental reninangiotensin system in normal and pre-eclamptic pregnancies. 
Therapeutic Advances in Cardiovascular Disease 20082 349-362. (doi:10.1177/1753944708094529)

7 Merrill DC, Karoly M, Chen K, Ferrario CM \& Brosnihan KB. Angiotensin-(1-7) in normal and preeclamptic pregnancy. Endocrine 200218 239-245. (doi:10.1385/ENDO:18:3:239)

8 AbdAlla S, Lother H, el Massiery A \& Quitterer U. Increased AT(1) receptor heterodimers in preeclampsia mediate enhanced angiotensin II responsiveness. Nature Medicine 20017 1003-1009. (doi:10.1038/ nm0901-1003)

9 Quitterer U, Lother H \& Abdalla S. AT1 receptor heterodimers and angiotensin II responsiveness in preeclampsia. Seminars in Nephrology 200424 115-119. (doi:10.1016/j.semnephrol.2003.11.007)

10 Herse F \& LaMarca B. Angiotensin II type 1 receptor autoantibody (AT1-AA)-mediated pregnancy hypertension. American Journal of Reproductive Immunology 201369 413-418. (doi:10.1111/aji.12072)

11 Wallukat G, Homuth V, Fischer T, Lindschau C, Horstkamp B, Jupner A, Baur E, Nissen E, Vetter K, Neichel D et al. Patients with preeclampsia develop agonistic autoantibodies against the angiotensin AT1 receptor. Journal of Clinical Investigation 1999103 945-952. (doi:10.1172/JCI4106)

12 Zhou CC, Zhang Y, Irani RA, Zhang H, Mi T, Popek EJ, Hicks MJ, Ramin SM, Kellems RE \& Xia Y. Angiotensin receptor agonistic autoantibodies induce pre-eclampsia in pregnant mice. Nature Medicine 200814 855-862. (doi:10.1038/nm.1856)

13 Granger JP, LaMarca BB, Cockrell K, Sedeek M, Balzi C, Chandler D \& Bennett W. Reduced uterine perfusion pressure (RUPP) model for studying cardiovascular-renal dysfunction in response to placental ischemia. Methods in Molecular Medicine 2006122 383-392.

14 LaMarca B, Wallukat G, Llinas M, Herse F, Dechend R \& Granger JP. Autoantibodies to the angiotensin type I receptor in response to placental ischemia and tumor necrosis factor $\alpha$ in pregnant rats. Hypertension 200852 1168-1172. (doi:10.1161/HYPERTENSIONAHA. 108.120576)

15 Rossitto G, Regolisti G, Rossi E, Negro A, Nicoli D, Casali B, Toniato A, Caroccia B, Seccia TM, Walther T et al. Elevation of angiotensin-II type-1-receptor autoantibodies titer in primary aldosteronism as a result of aldosterone-producing adenoma. Hypertension $2013 \mathbf{6 1}$ 526-533. (doi:10.1161/HYPERTENSIONAHA.112.202945)

16 Kem DC, Li H, Velarde-Miranda C, Liles C, Vanderlinde-Wood M, Galloway A, Khan M, Zillner C, Benbrook A, Rao V et al. Autoimmune mechanisms activating the angiotensin AT1 receptor in 'primary' aldosteronism. Journal of Clinical Endocrinology and Metabolism 201499 1790-1797. (doi:10.1210/jc.2013-3282)

17 Hopkins MP. Report of the National High Blood Pressure Education Program Working Group on High Blood Pressure in Pregnancy. American Journal of Obstetrics and Gynaecology 2000183 1-258. (doi:10.1067/mob.2000.107928)

18 Wyckoff JA, Seely EW, Hurwitz S, Anderson BF, Lifton RP \& Dluhy RG. Glucocorticoid-remediable aldosteronism and pregnancy. Hypertension 200035 668-672. (doi:10.1161/01.HYP.35.2.668)

19 Zezza L, Ralli E, Conti E, Passerini J, Autore C \& Caserta D. Hypertension in pregnancy: the most recent findings in pathophysiology, diagnosis and therapy. Minerva Ginecologica 201466 103-126.

20 Okawa T, Asano K, Hashimoto T, Fujimori K, Yanagida K \& Sato A. Diagnosis and management of primary aldosteronism in pregnancy: case report and review of the literature. American Journal of Perinatology 200219 031-036. (doi:10.1055/s-2002-20170)

21 Cabassi A, Rocco R, Berretta R, Regolisti G \& Bacchi-Modena A. Eplerenone use in primary aldosteronism during pregnancy. Hypertension 201259 e18-e19. (doi:10.1161/HYPERTENSIONAHA. 111.187237)

22 Kosaka K, Onoda N, Ishikawa T, Iwanaga N, Yamamasu S, Tahara H, Inaba $\mathrm{M}$, Ishimura $\mathrm{E}$, Ogawa $\mathrm{Y} \&$ Hirakawa K. Laparoscopic adrenalectomy on a patient with primary aldosteronism during pregnancy. Endocrine Journal 200653 461-466. (doi:10.1507/endocri.K05-122)
23 Shalhav A, Landman J, Afane J, Levi R \& Clayman RV. Laparoscopic adrenalectomy for primary hyperaldosteronism during pregnancy. Journal of Laparoendoscopic \& Advanced Surgical Techniques $2000 \mathbf{1 0}$ 169-171. (doi:10.1089/lap.2000.10.169)

24 Shigematsu K, Nishida N, Sakai H, Igawa T, Suzuki S, Kawai K \& Takahara O. Primary aldosteronism with aldosterone-producing adenoma consisting of pure zona glomerulosa-type cells in a pregnant woman. Endocrine Pathology 200920 66-72. (doi:10.1007/s12022-0099060-8)

25 Nezu M, Miura Y, Noshiro T \& Inoue M. Primary aldosteronism as a cause of severe postpartum hypertension in two women. American Journal of Obstetrics and Gynaecology 2000182 745-746. (doi:10.1067/ mob.2000.104229)

26 Nursal TZ, Caliskan K, Ertorer E, Parlakgumus A \& Moray G. Laparoscopic treatment of primary hyperaldosteronism in a pregnant patient. Canadian Journal of Surgery 200952 E188-E190.

27 Albiger N, Sartorato P, Mariniello B, Iacobone M, Finco I, Fassina A \& Mantero F. A case of primary aldosteronism in pregnancy: do LH and GNRH receptors have a potential role in regulating aldosterone secretion? European Journal of Endocrinology 2011164 405-412. (doi:10.1530/EJE-10-0879)

28 Robar CA, Poremba JA, Pelton JJ, Hudson L \& Higby K. Current diagnosis and management of aldosterone-producing adenomas during pregnancy. Endocrinologist 19988 403-408. (doi:10.1097/ 00019616-199811000-00003)

29 Matsumoto J, Miyake H, Isozaki T, Koshino T \& Araki T. Primary aldosteronism in pregnancy. Journal of Nippon Medical School 200067 275-279. (doi:10.1272/jnms.67.275)

30 Al-Ali N, El-Sandabesee D, Steel S \& Roland J. Conn's syndrome in pregnancy successfully treated with amiloride. Journal of Obstetrics and Gynaecology 200727 730-731. (doi:10.1080/01443610701667098)

31 Kreze A Jr, Kothaj P, Dobáková M \& Rohon S. Primary aldosteronism caused by aldosterone-producing adenoma in pregnancy - complicated by EPH gestosis. Wiener Klinische Wochenschrift 1999111 855-857.

32 Germain A, Kottman C \& Valdes G. Primary aldosteronism and pregnancy: report of 2 cases. Revista Medica de Chile 2002130 1399-1405. (doi:10.4067/S0034-98872002001200010)

33 Krysiak R, Samborek M \& Stojko R. Primary aldosteronism in pregnancy. Acta Clinica Belgica 201267 130-134. (doi:10.1179/ACB.67. 2.2062644)

34 Riester A, Fischer E, Degenhart C, Reiser MF, Bidlingmaier M, Beuschlein F, Reincke M \& Quinkler M. Age below 40 or a recently proposed clinical prediction score cannot bypass adrenal venous sampling in primary aldosteronism. Journal of Clinical Endocrinology and Metabolism 201499 E1035-E1039. (doi:10.1210/jc.2013-3789)

35 Rossi GP, Bernini G, Caliumi C, Desideri G, Fabris B, Ferri C, Ganzaroli C, Giacchetti G, Letizia C \& Maccario M. A prospective study of the prevalence of primary aldosteronism in 1,125 hypertensive patients. Journal of the American College of Cardiology 200648 2293-2300. (doi:10.1016/j.jacc.2006.07.059)

36 Pallauf A, Schirpenbach C, Zwermann O, Fischer E, Morak M, Holinski-Feder E, Hofbauer L, Beuschlein F \& Reincke M. The prevalence of familial hyperaldosteronism in apparently sporadic primary aldosteronism in Germany: a single center experience. Hormone and Metabolic Research 201244 215-220. (doi:10.1055/ s-0031-1299730)

37 Goland RS, Wardlaw SL, Stark RI, Brown LS Jr \& Frantz AG. High levels of corticotropin-releasing hormone immunoactivity in maternal and fetal plasma during pregnancy. Journal of Clinical Endocrinology and Metabolism 198663 1199-1203. (doi:10.1210/jcem-63-5-1199)

38 Mulatero P, di Cella SM, Williams TA, Milan A, Mengozzi G, Chiandussi L, Gomez-Sanchez CE \& Veglio F. Glucocorticoid remediable aldosteronism: low morbidity and mortality in a four-generation Italian pedigree. Journal of Clinical Endocrinology and Metabolism 200287 3187-3191. (doi:10.1210/jcem.87.7.8647) 
39 Ronconi V, Turchi F, Zennaro MC, Boscaro M \& Giacchetti G Progesterone increase counteracts aldosterone action in a pregnant woman with primary aldosteronism. Clinical Endocrinology $2011 \mathbf{7 4}$ 278-279. (doi:10.1111/j.1365-2265.2010.03901.x)

40 Rigo J Jr, Glaz E \& Papp Z. Low or high doses of spironolactone for treatment of maternal Bartter's syndrome. American Journal of Obstetrics and Gynaecology 1996174 297. (doi:10.1016/S0002-9378(96)70418-0)

41 Groves TD \& Corenblum B. Spironolactone therapy during human pregnancy. American Journal of Obstetrics and Gynaecology 1995172 1655-1656. (doi:10.1016/0002-9378(95)90549-9)

42 American College of Obstetricians and Gynecologists; Task Force on Hypertension in Pregnancy. Hypertension in pregnancy. Report of the American College of Obstetricians and Gynecologists' Task Force on Hypertension in Pregnancy. Obstetrics and Gynaecology 2013 122 1122-1131. (doi:10.1097/01.AOG.0000437382.03963.88)

43 Funder JW, Carey RM, Fardella C, Gomez-Sanchez CE, Mantero F, Stowasser M, Young WF Jr \& Montori VM. Case detection, diagnosis, and treatment of patients with primary aldosteronism: an endocrine society clinical practice guideline. Journal of Clinical Endocrinology and Metabolism 200893 3266-3281. (doi:10.1210/jc. 2008-0104)

44 Kamoun M, Mnif MF, Charfi N, Kacem FH, Naceur BB, Mnif F, Dammak M, Rekik N \& Abid M. Adrenal diseases during pregnancy: pathophysiology, diagnosis and management strategies. American Journal of Medical Sciences 2014347 64-73. (doi:10.1097/MAJ. Ob013e31828aaeee)

45 Rossi GP, Auchus RJ, Brown M, Lenders JW, Naruse M, Plouin PF, Satoh F \& Young WF. An expert consensus statement on use of adrenal vein sampling for the subtyping of primary aldosteronism. Hypertension 201463 151-160. (doi:10.1161/HYPERTENSIONAHA.113.02097)

46 Funder J. Evolution of how best to manage primary aldosteronism. Foreword. Reviews in Endocrine and Metabolic Disorders 2011121. (doi:10.1007/s11154-011-9173-5)

47 Higgins HP \& O'Sullivan M. Use of an aldosterone antagonist in the diagnosis of primary hyperaldosteronism. Canadian Medical Association Journal 196083 1289-1292.

48 Morton A, Panitz B \& Bush A. Eplerenone for gitelman syndrome in pregnancy. Nephrology 201116 349. (doi:10.1111/j.1440-1797.2010. 01396.x)

49 Nocke L, Breuer H, Klink R, Lichton IR \& Nocke W. Influence of spironolactone on the excretion of C21-, C19-, and C18 steroids in pregnant and nonpregnant women. Acta Endocrinologica Supplementum 197115241

50 Lammintausta R \& Erkkola R. Effect of spironolactone treatment on the renin-aldosterone system during pregnancy. International Journal of Clinical Pharmacology and Biopharmacy 197917 294-298.

51 Rose LI, Regestein Q \& Reckler JM. Lack of effect of spironolactone on male genital development. Investigative Urology 197513 95-96.

52 Hecker A, Hasan SH \& Neumann F. Disturbances in sexual differentiation of rat foetuses following spironolactone treatment. Acta Endocrinologica 198095 540-545.

53 Shah A. Ambiguous genitalia in a newborn with spironolactone exposure, 93rd Annual Meeting of the Endocrine Society: abstr., Vol 4, P3-227, 2011.

54 Nohira T, Nakada T, Akutagawa O, Fujito A, Okabe K, Ioya N \& Yoshida M. Pregnancy complicated with Bartter's syndrome: a case report. Journal of Obstetrics and Gynaecology Research 200127 267-274. (doi:10.1111/j.1447-0756.2001.tb01268.x)

55 de Arriba G, Sanchez-Heras M \& Basterrechea MA. Gitelman syndrome during pregnancy: a therapeutic challenge. Archives of Gynecology and Obstetrics 2009280 807-809. (doi:10.1007/s00404-009-0994-3)

56 Rušavý Z, Hudec A, Karbanová J, Korečko V, Janů R \& Kališ V. Gitelman syndrome in pregnancy - a severe hypokalemia with favorable perinatal prognosis. Ceská gynekologie/Ceská lékarská spolecnost Jan Evangelista Purkyne 201277 421-423.

57 Levy J \& Marx GF. Problems related to aldosteronism during cesarean section. Anesthesiology 197134 294-297. (doi:10.1097/00000542197103000-00021)

58 Lotgering FK, Derkx FM \& Wallenburg H. Primary hyperaldosteronism in pregnancy. American Journal of Obstetrics and Gynaecology 1986155 986-988. (doi:10.1016/0002-9378(86)90331-5)

59 Crane MG, Andes JP, Harris JJ \& Slate WG. Primary aldosteronism in pregnancy. Obstetrics and Gynaecology 196423 200-208.

60 Craft J. Eplerenone (Inspra), a new aldosterone antagonist for the treatment of systemic hypertension and heart failure. Proceedings (Baylor University. Medical Center) 200417 217-220.

61 Hutter DA, Berkowitz R, Davis SE \& Ashtyani H. Application of continuous positive airway pressure in hypoxemic acute respiratory failure associated with diastolic dysfunction in pregnancy. Congestive Heart Failure 200612 174-175. (doi:10.1111/j.1527-5299. 2005.05316.x)

Received 31 May 2014

Revised version received 12 August 2014

Accepted 26 August 2014 